\title{
Vertical transport systems for evacuation from high-rise buildings
}

\author{
Marina Gravit ${ }^{1}$, Ivan Dmitriev ${ }^{1, *}$, Kirill Kuzenkov ${ }^{1}$ and Alena Shestakova ${ }^{2}$ \\ ${ }^{1}$ Peter the Great St. Petersburg Polytechnic University, 29 Politechnicheskaya St., St. Petersburg, \\ 195251, Russia \\ ${ }^{2}$ Tyumen Industrial University, Volodarskogo str., 38, Tyumen, 625000, Russia
}

\begin{abstract}
The article discusses the possibility of using the elevators as the main evacuation path from high-rise buildings. It starts by analysis of the reasons, which make effective evacuation of people from high-rise buildings difficult. The high multi-storey office building was modelled in the Pathfinder software package. There are presented some scenarios of the human flow and their influence on time parameters (the evacuation start and signal delivery delay), on flow composition (ratio of people with different mobility) and base evacuation level of each group. The time of evacuation is compared on the staircase and using elevators. It is effective to use evacuation elevators in 60 -storey buildings, but it is not rational to use them in 20 -storey building.
\end{abstract}

\section{Introduction}

The number of high-rise buildings increases every year. There are special fire safety requirements in such buildings [1-3], but evacuation path remains too long so even healthy people will suffer from fatigue when they move to such distances. The evacuation becomes especially difficult, dangerous and sometimes physically impossible for orderly people and people with reduced mobility (PRM) [4]. It is noted in article [5] that the staircases do not provide sufficient capacity to organize the evacuation of people from a high-rise building.

A number of reasons are presented that prevent the introduction of evacuation lifts:

- spread of the smoke and poisonous combustion products through lift shaft;

- power outage;

- stopping the elevator on a floor covered by fire;

- deformation and jamming of elevator doors on the floor of the fire;

- getting water in extinguishing a fire in the elevator shaft;

- possible overflow of elevator cabins by evacuating people.

Investigations of people's behavior during the fire [6,7] reveal that some people use elevators during the evacuation if they are not deactivated. This value reaches $15 \%$ in fivestory houses and $67 \%$ in twenty-storey buildings of hotels. It is worth mentioning that evacuation from the Twin Towers after the terrorist act with the help of elevators saved up to 3000 lives [8].

"Corresponding author: i.i.dmitriev@yandex.ru 
The most accurate algorithm is realized in the PC Pathfinder model, which presupposes the intellectual movement of people (maneuvering, avoidance of collision, acceleration in the presence of free space) [9]. However, the authors of [10] note that the results of modelling evacuation depend on the program algorithm and, for example, the results of modelling in Pathfinder may be understated because of the high traffic intensity of human flow through local narrow places. One example of successful evacuation modelling in the Pathfinder program is the calculation of the fire safety of the university library in Nanjing [11].

The article [12] emphasizes that a person spends part of the time for investigation of emergency cause and collection of things, and this delay is the main cause of injury and death of people [13]. People also react to the alarm for a long time [14, 15].

Progressive fire extinguish systems and traditional solutions are used for fire safety in "Lakhta Center" [16]. The aim of fire protection system is preventing fire case, human security and property protection. The human evacuation from the building floors is provided by several variants:

- Safety corridors - corridor with wall resistance not less than REI 120 and smoke ventilation system. This is the way to safe people movement to the stair;

- Two smoke proof stairways, which are equipped with air boosting device and entrance through pressurized lobby;

- Two emergency exits to the evacuation stairwell. Evacuation from the upper level of observation deck provides through the curved ramp with a slope or on staircase;

- All escape routes have such width that it could easily carry a stretcher.

Lakhta Center fire subsections elevators are used as ordinary lifts in normal conditions. These elevators stop at all floors above ground that provides free access for firefighters to all apartments, including technical.

The firefighter elevators are made in a separate shaft and have self-closing doors with fire resistance REI 30. Evacuation is carried out with the help of elevators. The main input groups are located on three levels.

The article purpose is possibility justification of using elevators in the human evacuation from high-rise buildings and structures. To achieve this goal, the following tasks were accomplished:

1) A high-rise multi-storey office building was modelled in the Pathfinder software package. The following dependencies of the evacuation time on the parameters of the movement of people of different health categories were considered:

- Estimated time using an exceptional staircase (except M4);

- Time of evacuation during the movement of persons of categories M2, M3 and M4 through elevators;

- Flow control M1. Partial evacuation of persons of this category through elevators.

2) Comparison of the evacuation time on the staircases and through elevators.

\section{Methods}

A tall multi-storey building was modelled in the Pathfinder program. The evacuation time was calculated using both ladders exclusively and with partial use of vertical elevator units. Dependences of the most optimal percentage of people using the first and second versions of evacuation routes are obtained. The calculations were carried out taking into account the presence of an immobile population group. 


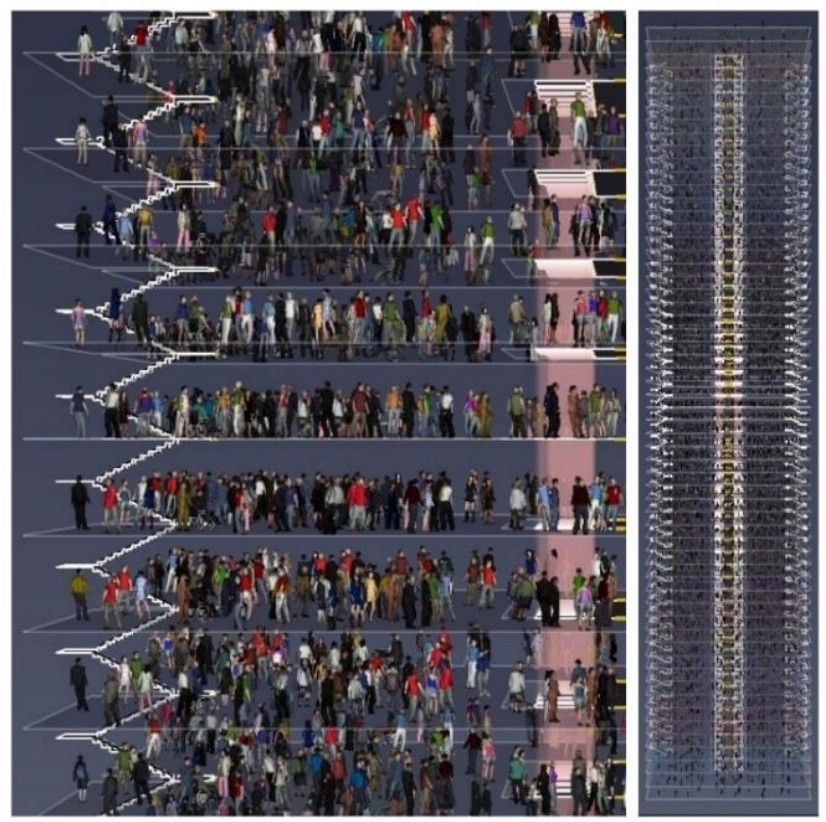

Fig. 1. The model of high-rise building in the Pathfinder program

Parameters of a high-rise multi-storey building:

- Number of floors -60 pcs. The building is divided into 3 sections of 20 floors;

In each twenty-storey section:

- Height of the floor is 3 meters;

- Useful floor area $600 \mathrm{~m}^{2}$;

- 100 people per floor (at the rate of 1 person per $6 \mathrm{~m}^{2}$ usable area). The ratio of people in the health groups M1, M2, M3, M4 is taken to be 90, 4, 4, 2; In the calculation, an excessive number of individuals of PRM (10\%) was accepted because of the demographic trend of maintaining the working capacity of the population of retirement age and in conditions of environmental accessibility [17];

- Two U-shaped staircases H3 type, a march is $1350 \mathrm{~mm}$;

- 6 elevators for 13 people $\left(\mathrm{a}=1.2 \mathrm{~m} / \mathrm{s}^{2}, \mathrm{v}(\max )=2.5 \mathrm{~m} / \mathrm{s}\right)$ inside the block for 20 floors. These elevators move inside the section;

- 4 lift-shuttles for 26 people $\left(\mathrm{a}=1.2 \mathrm{~m} / \mathrm{s}^{2}, \mathrm{v}(\max )=4 \mathrm{~m} / \mathrm{s}\right)$ are vertical connections of the 1 st floor of the building and the 1 st floor of sections 2 and $3\left(20^{\text {th }}\right.$ and $40^{\text {th }}$ respectively). There are two lifts per section;

- $\quad$ The project provides for two safety zones - 20 and 40 floors [18];

- $t_{s t . e v}=2.8$ minutes (Time of start evacuation is a time after alert and before beginning human movement. It should be added to the estimated time to obtain the most reliable result) [19].

In Figure 1 there is the 3D Pathfinder section and in Figure $23 \mathrm{D}$ section view of the modelled building with the notation of safety zones, lifts which move inside the section and lift shutters. 


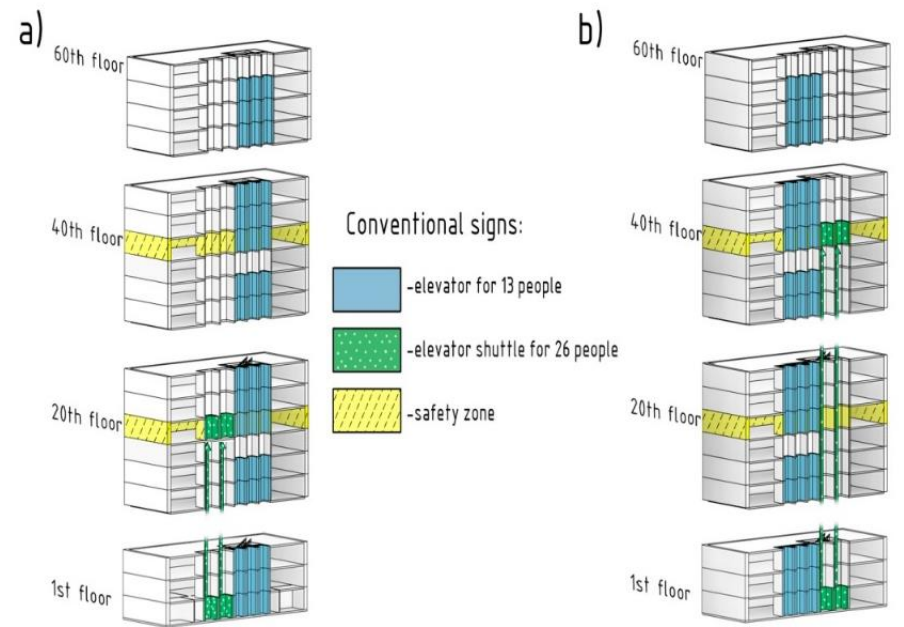

Fig. 2. Section of a simulated office building:

a) Movement of the elevator-shuttle from the first floor to the $20^{\text {th }}$;

b) Movement of the elevator-shuttle from the first floor to the $40^{\text {th }}$.

\section{Results}

The analysis of the dependence of the number evacuated people from the time showed that completion of evacuation on the staircases and through the elevators was not simultaneous. Some people of category M1 continue to descend the staircases after the end of the use of elevators by M2, M3 and M4. This leads to an increase in the final period of evacuation. We consider the situation when some people M1 mobility category also use an elevator to descend to the base floor and find the most effective percentage of the persons M1 category. Results are in the table 1.

Table 1 Influence on the total evacuation time of the partial movement of the flow M1 through elevators in a separate section 1-19 floor.

\begin{tabular}{|c|c|c|c|}
\hline No & Description & Use lift & Time (sec) \\
\hline 1 & $\begin{array}{l}30 \% \mathrm{M} 1 \text { is directed through the evacuation } \\
\text { elevator from the } 4^{\text {th }} \text { floor }\end{array}$ & $\begin{array}{c}\text { M4 (100\%) 1-19 } \\
\text { M2 and M3 (100\%) 4-19 } \\
\text { M1 (30\%) 7-19 }\end{array}$ & 780 \\
\hline 2 & $\begin{array}{l}30 \% \mathrm{M} 1 \text { is directed through the evacuation } \\
\text { elevator from the } 7^{\text {th }} \text { floor }\end{array}$ & $\begin{array}{c}\text { M4 (100\%) 1-19 } \\
\text { M2 and M3 (100\%) 7-19 } \\
\text { M1 (30\%) 7-19 }\end{array}$ & 723 \\
\hline 3 & $\begin{array}{l}30 \% \mathrm{M} 1 \text { is directed through the evacuation } \\
\text { elevator from the } 10^{\text {th }} \text { floor }\end{array}$ & $\begin{array}{c}\text { M4 (100\%) 1-19 } \\
\text { M2 and M3 (100\%) 7-19 } \\
\text { M1 (30\%) 10-19 }\end{array}$ & 735 \\
\hline 4 & $\begin{array}{l}30 \% \mathrm{M} 1 \text { is directed through the evacuation } \\
\text { elevator from the } 13^{\text {th }} \text { floor }\end{array}$ & $\begin{array}{c}\text { M4 (100\%) 1-19 } \\
\text { M2 and M3 (100\%) 7-19 } \\
\text { M1 }(40 \%) 13-19\end{array}$ & 791 \\
\hline 5 & $\begin{array}{l}40 \% \mathrm{M} 1 \text { is directed through the evacuation } \\
\text { elevator from the } 7^{\text {th }} \text { floor }\end{array}$ & $\begin{array}{c}\text { M4 (100\%) 1-19 } \\
\text { M2 and M3 (100\%) 7-19 } \\
\text { M1 }(40 \%) 7-19\end{array}$ & 788 \\
\hline 6 & $\begin{array}{l}40 \% \mathrm{M} 1 \text { is directed through the evacuation } \\
\text { elevator from the } 10^{\text {th }} \text { floor }\end{array}$ & $\begin{array}{c}\text { M4 (100\%) 1-19 } \\
\text { M2 and M3 (100\%) 7-19 } \\
\text { M1 }(40 \%) 10-19\end{array}$ & 742 \\
\hline
\end{tabular}


We took the $7^{\text {th }}$ floor as a start evacuation level of PRM citizens M2 and M3. The fastest partial evacuation of people in the ratio of $30 \% \mathrm{M} 1$ was sent to evacuation via elevator from $7^{\text {th }}$ to $14^{\text {th }}$ floor, $40 \%$ of M1 was sent for evacuation via elevator from the $15^{\text {th }}$ to the $19^{\text {th }}$ floor.

Table 2. Summary table of variations in evacuation parameters of section 1-19 floor

\begin{tabular}{|c|c|c|c|}
\hline No & Description & Use lift & Time (sec) \\
\hline 1 & Only the ladder for M1, M2, M3 & M4 (100\%) 1-19 & 1043 \\
\hline 2 & $\begin{array}{l}\text { Elevators collect M2, M3 } \\
\text { From } 7^{\text {th }} \text { to } 19^{\text {th }} \text { floor }\end{array}$ & $\begin{array}{c}\text { M4 (100\%) 1-19 } \\
\text { M2 and M3 (100\%) 7-19 }\end{array}$ & 888 \\
\hline 3 & $\begin{array}{c}30 \% \text { of M1 is sent for evacuation via } \\
\text { elevator } \\
\text { From the } 7^{\text {th }} \text { floor }\end{array}$ & $\begin{array}{c}\text { M4 }(100 \%) 1-19 \\
\text { M2 and M3 (100\%) 7-19 } \\
\text { M1 (30\%) 7-19 }\end{array}$ & 723 \\
\hline 4 & $\begin{array}{l}30 \% \text { of } \mathrm{M} 1 \text { is sent for evacuation via } \\
\text { elevator from } 7^{\text {th }} \text { to } 14^{\text {th }} \text { floor } \\
40 \% \text { of } \mathrm{M} 1 \text { is sent for evacuation via } \\
\text { elevator from } 15^{\text {th }} \text { to } 19^{\text {th }} \text { floor }\end{array}$ & $\begin{array}{c}\text { M4 }(100 \%) 1-19 \\
\text { M2 and M3 (100\%) 7-19 } \\
\text { M1 (30\%) 7-14 } \\
\text { M1 (40\%) 15-19 }\end{array}$ & 687 \\
\hline
\end{tabular}

The results were obtained with allowance for the delay (0-120-0-240-0-360), which turned out to be the most effective according to the calculation results. There is a consistent decrease in the total evacuation time if they use measures of human flow regulation. The final comparison of the evacuation time for the entire building and for the section on the staircases and using through the elevators is summarized in Table 3.

Table 3. Summary table of evacuation parameters of the section and the whole building

\begin{tabular}{|c|c|c|c|c|c|}
\hline No & Description & $\begin{array}{c}\text { Time (ladder } \\
\text { only), sec }\end{array}$ & $\begin{array}{c}\text { Time (use } \\
\text { elevators), sec }\end{array}$ & $\begin{array}{c}\text { Time of } \\
\text { improvement, } \\
\text { sec }\end{array}$ & $\begin{array}{c}\text { Improvement } \\
\text { percentage, } \\
\text { \% }\end{array}$ \\
\hline 1 & $\begin{array}{c}\text { Section } \\
\text { 1-19 level }\end{array}$ & 1043 & 687 & $356(6 \mathrm{~min})$ & 34 \\
\hline 2 & $\begin{array}{c}\text { Building 1-60 } \\
\text { level }\end{array}$ & 2998 & 2032 & $966(16 \mathrm{~min})$ & 32 \\
\hline
\end{tabular}

The use of elevators reduces evacuation time by an average of $30 \%$. The use of elevators and the management of the human flow reduces the duration of the evacuation by only 6 minutes for a twenty-story building, which raises some questions about the necessary of using this technical equipment as the main evacuation path. However, in a high-rise 60 -storey office building with a high people density, the improvement of the result exceeds 15 minutes. This result is a fairly large indicator, significantly reducing the time people stay in the building with a fire.

The diagram in Figure 3 shows the movement of human flows during the evacuation of the entire building.

The unevenness at the end of the graph is due to the lack of human flow settings regarding the shuttles connecting the base floor of the section and the first floor of the building. If the graph extends to the ideal case of linear dependence, the time will be reached when the liftsshuttles and staircases bring the evacuated to the first floor simultaneously. Thus, it is possible to obtain a minimum evacuation time with simultaneous use of elevators and shuttles, equal to 1770 seconds. This value is obtained by sequential interpolation of the graph. 


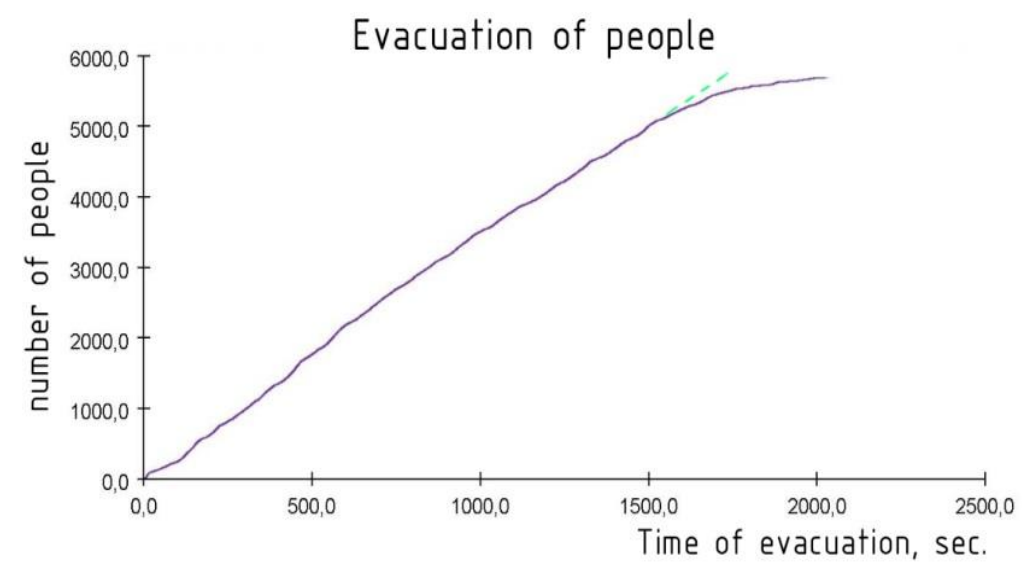

Fig. 3. The diagram of human flows during the evacuation.

\section{Conclusions}

The analysis of the reasons preventing effective evacuation from high-rise buildings has shown that it is difficult even for fully healthy people to overcome long distances of the evacuation path. This problem is especially actual for persons with reduced mobility, including orderly people, for which great physical exertion can cause additional difficulties.

1. Several scenarios of the flow of human flow are presented. It is shown the influence on evacuation time of some parameters as the beginning of evacuation and delay of signal delivery, the composition of the flow (people with different mobility), and the level at which the evacuation of each group begins. The evacuation time is calculated with and without using elevators.

2. Comparison of the evacuation time on the staircase and through elevators showed that for a 20-storey building it is not rational to use the elevator system as one of the main evacuation path, but for a 60 -storey building it is very effective. In the future, it is necessary to consider the organization evacuation with the use of elevators.

\section{References}

1. M. Gravit, E. Mikhailov, S. Svintsov, A. Kolobzarov, I. Popovych, Materials Science Forum, 871, 138-145 (2016).

2. M. Gravit, A. Vaititckii, M. Imasheva, D. Nigmatullina, A. Shpakova, MATEC Web of Conferences, 53, 01031(2016).

3. M. Gravit, E. Nedviga, N. Vinogradova, Z. Teplova, MATEC Web of Conferences, 106, 02025 (2017)

4. V.V. Kholshchevnikov, D.A. Samoshin, Fire and Explosion Safety, 15(5), 45-47 (2006).

5. R. M. Patton, ASHRAE Journal, 15(14), 34-41 (1973).

6. M.L. Siikonen, K. Barlund, R. Kontturi, ASME Workshop to Focus on Elevator Emergencies in High-Rise Buildings. (New York, 2003).

7. A. Sekizawa, S. Nakahama, H. Notake, ASME Workshop to Focus on Elevator Emergencies in High-Rise Buildings. (New York, 2003).

8. Final Report on Collapse of the World Center Towers, NIST NCSTAR, 1, (USA, 2005).

9. D.A. Samoshin, Fire safety in construction, 1, 62-65 (2011). 
10. D.A. Samoshin, D.P. Deryugin, Technology of technospheric security, 6 (64), 110-119 (2015).

11. M.X. Li, S.H. Zhu, J.H. Wang, Z. Zhou, Procedia Engineering, 211, 372-378 (2018).

12. D.A. Samoshin Fire and Explosion Safety, 1, 33-46 (2004).

13. P. Brennan, I. Tomas Second International Symposium on Human Behaviour in Fire (MIT, Boston, Interscience Communication Ltd, 2001).

14. D.A. Samoshin, K.E. Boyce, T.J. Shields, Proceedings of the Eighth International Symposium Fire Safety Science (Beijing, China, 2005).

15. D. Shilds, K.Ye. Boys, V.V. Kholshchevnikov, D.A. Samoshin, Fire and Explosion Safety. 1, 44-52 (2005).

16. Lakhta Center Lift [Electronic resource]. Free access: https://lakhta.center/ru/about/hightech/lifts/

17. Set of Rules 59.13330.2012 Availability of buildings and structures for low-mobility groups of the population.

18. Ad. Cowlard, Ad. Bittern, C. Abecassis-Empis, J. Torero, Procedia Engineering, 62, 169-181 (2013).

19. T.G. Merkushkina, D.A. Samoshin, Z.S. Khasuyeva, M.Yu Zykova. Technology of technospheric security, 5 (63), 73-81 (2015). 